\title{
塗装補修された金属被覆鋼板の 防食性能劣化特性に関する研究
}

\author{
伊藤 義人 1 ・細井 章浩 $2 \cdot$ 北根 安雄 $3 \cdot$ 杉浦 友樹 $4 \cdot$ 栗田 光二 5 \\ 1フェロー会員 名古屋大学大学院教授 工学研究科（†464-8603 名古屋市千種区不老町） \\ E-mail: itoh@civil.nagoya-u.ac.jp \\ 2正会員 株式会社IHIインフラシステム 橋梁設計部（テ590-0977 大阪府堺市堺区大浜西町3番地） \\ E-mail: akihiro_hosoi@iis.ihi.co.jp \\ 3正会員 名古屋大学大学院准教授 工学研究科（广464-8603 名古屋市千種区不老町） \\ E-mail: ykitane@civil.nagoya-u.ac.jp \\ 4非会員 株式会社 NTTデータ（†135-6033 東京都江東区豊洲3-3-3 豊洲センタービル） \\ E-mail: sugiurayu@nttdata.co.jp \\ 5 学生会員 名古屋大学工学部社会環境工学コース（†464-8603 名古屋市千種区不老町） \\ E-mail: kurita@struct.civil.nagoya-u.ac.jp
}

\begin{abstract}
本研究は，溶融亜鉛めっき，亜鉛アルミ合金溶射，亜鉛アルミ擬合金溶射およびアルミ溶射による金属 皮膜の劣化後に重防食塗装系による塗装補修を行った鋼板供試体に対し，300日間にわたる長期間の酸性雨 噴霧複合サイクルの環境促進実験を行い, その防食性能劣化特性を検討した。 その結果, 溶融刺鉛めっき の残存皮膜は，塗装の防食下地として有効に作用し，防食性能を高めるが，亜鉛アルミ合金溶射，亜鉛ア ルミ擬合金溶射およびアルミ溶射の金属皮膜は，残存金属皮膜厚が厚い部分で補修塗膜に欠陥が生じた場 合，塗装の防食性能を低下させることが分かった。また，実験からの知見をもとに，塗装補修における留 意点と施工法を検討し，一般環境下と酸性雨環境下での金属被覆防食のライフサイクルコストを算定し， 防食システムの維持管理法を明らかにした。
\end{abstract}

Key Words : repair painting, accelerated exposure test, acid rain, metallic coating

\section{1. はじめに}

長期にわたり良好な防食性能を有し，ライフサイクル コストなどで優位な場合があることから，鋼橋において も，亜鉛めっきや各種の金属溶射による金属被覆防食が 用いられるようになってきている．金属被覆の防食性能 に関しては, 実橋梁調査 ${ }^{1}{ }^{1}$ や種々の大気暴露試験 $\left.{ }^{2} \sim 5\right)$ によ って, 腐食環境が厳しい海岸・海洋地域においても 30 年 以上にわたり良好な防食性能を有寸る場合があることが 報告されている．しかしながら，金属被覆防食の防食機 能は，金属皮膜の腐食特性に大きく依存していることか ら，酸性雨環境下においては，その防食性能が著しく低 下寸る場合があることが, 伊藤らの環境促進実験 ${ }^{6}$ (以下， 前実験と称す）によって判明している.

金属皮膜劣化後の補修方法については，溶射によって 再度金属皮膜を形成する手法もあるが，更新費用が大き く, 施工についても専門性が必要であり，現状ではすぐ
に広く普及することは困難である、鋼橋においても，維 持管理を含めたライフサイクル性能が重要視されている ため, 更新費用も安く, 施工も比較的容易な塗装による 補修で，なおかつライフサイクルコストを小さく抑えら れる補修方法の確立が望まれている.

塗装による防食において，塗膜下の黒皮や塩分および 旧塗膜などの残存異物が，その防食性能に大きな影響を 与えることが広く知られている ${ }^{799)}$. そのため, 塗替え 塗装においては，その塗膜の防食性能と同様に，素地調 整が重要である．しかしながら，劣化した金属被覆鋼板 の再防食処理を行うとき, 塗膜に比心強固な金属皮膜 (活 膜）が存在することから，ブラストによる金属皮膜の完 全な除去は容易でない. そのため, 健全な状態で残存し ている金属皮膜を残して補修が行われていることが多い. また，金属皮膜を下地として叙装を行う重防食について は，大気暴露試験 ${ }^{10}$ によって，その防食性能の検討が行 われた例はあるが，塗膜の寿命の延長などの効果は確認 


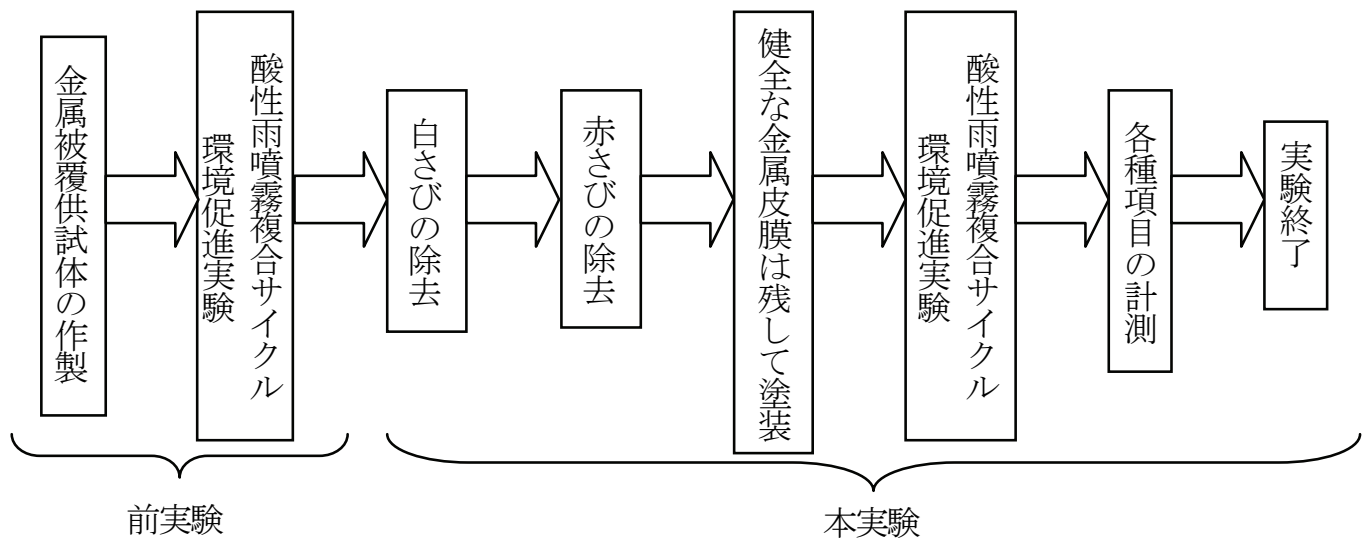

図-1 実験の流れ

表-1 前実験防食処理仕様

\begin{tabular}{|c|c|c|c|}
\hline 防食処理 & 処理工程 & 塗料名処理内容等 & $\begin{array}{c}\text { 目標膜)厚 } \\
(\mu \mathrm{m})\end{array}$ \\
\hline \multirow[b]{2}{*}{$\begin{array}{l}\text { 溶融亜鉛 } \\
\text { めつき }\end{array}$} & 前処理 & & \\
\hline & めつき処理 & $\begin{array}{l}\text { めつき槽温度 : 445 } \pm 5^{\circ} \mathrm{C}(7 \sim 8 \text { 分) } \\
\text { 冷却槽温度 : 50〜 } 60^{\circ} \mathrm{C} \text { (約 } 10 \text { 秒) }\end{array}$ & $\begin{array}{c}100 \\
\left(550 \mathrm{~g} / \mathrm{m}^{2}\right)\end{array}$ \\
\hline \multirow{6}{*}{$\begin{array}{c}\text { 亜鉛アルミ } \\
\text { 合金溶射 } \\
\text { (JIS 工法) }\end{array}$} & 素地調整 & ブラスト処理 $\quad$ SIS- Sa2.5 & - \\
\hline & プライマー & 無機ジンクリッチプライマー & (15) \\
\hline & 2 次素地調整 & ブラスト処理ＳIS-Sa2.5 & - \\
\hline & 粗面化処理 & & \\
\hline & 溶射 & 亜鉛アルミ合金被覆(Zn70Al30) & 100 \\
\hline & 封孔処理 & エポキシ樹脂溶射被覆封孔塗料 & - \\
\hline \multirow{6}{*}{$\begin{array}{c}\text { 西鉛アルミ } \\
\text { 擬合金溶射 } \\
\text { (MS 工法) }\end{array}$} & 素地調整 & ブラスト処理ＳIS- Sa2.5 & - \\
\hline & プライマー & 無機ジンクリッチプライマー & (15) \\
\hline & 2 次素地調整 & スイープブラスト( SIS-Sa1) & - \\
\hline & 粗面化処理 & 低温溶射用塗布型粗面形成剤 & - \\
\hline & 常温溶射 & 亜鉛アルミ擬合金被覆(Zn70Al30) & 100 \\
\hline & 封孔処理 & プチラール樹脂系溶射被覆封孔塗料 & - \\
\hline \multirow{6}{*}{ アルミ溶射 } & 素地調整 & ブラスト処理ＳIS- Sa2.5 & - \\
\hline & プライマー & 無機ジンクリッチプライマー & $(15)$ \\
\hline & 2 次素地調整 & ブラスト処理ＳIS-Sa2.5 & - \\
\hline & 粗面化処理 & & \\
\hline & 溶射 & アルミ被覆 & 100 \\
\hline & 封孔処理 & エポキシ樹脂溶射被覆封孔塗料 & - \\
\hline
\end{tabular}

されていない，そして，補修塗装時に活膜として残され た残存金属皮膜が補修塗装後の防食性能に及ぼす影響に 関しては十分な基礎的データが無い.

そこで，本研究では，環境促進実験を行い劣化させた 金属被覆鋼板（前実験）に，スイープブラストによるケ レンを行い，補修塗装により再度防食処理を施した供試 体と，新規の金属被覆鋼板に塗装を行った供試体を用い て，酸性雨噴霧環境促進実験（以下，本実験と称寸）を 行い, 金属被覆鋼板の塗装による補修性能と金属被覆+塗 装防食システムのライフサイクル性能を検討した.

\section{2. 実験手法}

\section{（1）実験概要}

環境促進実験による前実験 ${ }^{6)}$ と本実験の一連の流れを 図-1 に示寸．本実験では，表-1 に示す溶融亜鉛めっき， 亜鉛アルミ合金溶射，亜鉛アルミ擬合金溶射および アル ミ溶射の 4 種類の金属被覆鋼板供試体を環境促進実験に より劣化させ，スイープブラストによるケレンを行った 後に，塗装補修を施した供試体を用いて環境促進実験を 行った. 


\section{（2）環境促進実験条件}

前実験および本実験では，酸性雨噴霧複合サイクルに よる環境促進実験を行った。実環境との相関性が高いと いう研究成果 ${ }^{11}$ に基づいて, JIS K 5621 に規定されている S6 サイクルの環境促進実験条件を参考にし，5\%濃度の 塩化ナトリウム水溶液の噴霧を行う複合サイクルにおい て，水溶液を人工酸性雨に置き換えた。この人工酸性雨 はJIS H 8502 で規定されており，5\%濃度の塩化ナトリ ウム水溶液に硝酸と硫酸を加えた後， $10 \%$ 水酸化ナトリ ウム溶液を加えて $\mathrm{pH}$ を 3.5 に調整したものである.

実験には，複合サイクル試験機 CYP-90A（スガ試験機 株式会社製）を用いた. 実験供試体はJIS の規定に従い鋁 直方向から保持角 15 度で設置した. また, 25 日間ごとに 設置位置をローテーションさせることにより, 設置位置 による環境の違いを抑えた。

\section{（3）供試体}

前実験および本実験ともに実験供試体は，名古屋大学 型ウィザロ型供試体 ${ }^{6}$ とし，形状および寸法を図-2 に示 す. 本実験のクロスカット部は, 塗装補修後に前実験と 同一䇢所に設けた。 これは，同一条件下における防食シ ステムの性能を比較するためである.

まず，前実験として各金属被覆鋼板に対し 100 日間, 200 日間, および 300 日間の環境促進実験を実施し，金属 皮膜を劣化させた. その後, 白さびを除去した供試体の 金属皮膜の残存状況を図-3に示寸.

溶融亜鉛めっき

溶融覀鉛めっき被覆鋼板を 100 日間劣化させた供試体 （以下，亜鉛前実験 100 日供試体と称す）では，素地露 出部との上側境界とクロスカット直近において, 亜鉛皮
膜が他の一般部よりも多く残存していた。また，素地露 出部下部も金属皮膜は多く残存していた. 亜鉛前実験 300 日供試体では，クロスカット下部の金属皮膜の消耗が激 しかった. 一方，素地露出部下部は残存亜鉛皮膜が他の 一般部に比べると厚く残っていた.

亜鉛アルミ合金溶射

亜鉛アルミ合金溶射被覆鋼板を 100 日間劣化させた供 試体（以下，合金前実験 100 日供試体と称す）では，素 地露出部上部の素地露出部との境界から $2 \mathrm{~mm}$ 程度の区 間においては，金属皮膜の残存があつたが，素地露出部 下部の金属皮膜の消耗は激しかった.

\section{亜鉛アルミ擬合金溶射}

覀鉛アルミ擬合金溶射被覆鋼板を 200 日間劣化させた 供試体（以下，擬合金前実験 200 日供試体と称す）では， 素地露出部上部の素地露出部との境界から $3 \mathrm{~mm}$ から

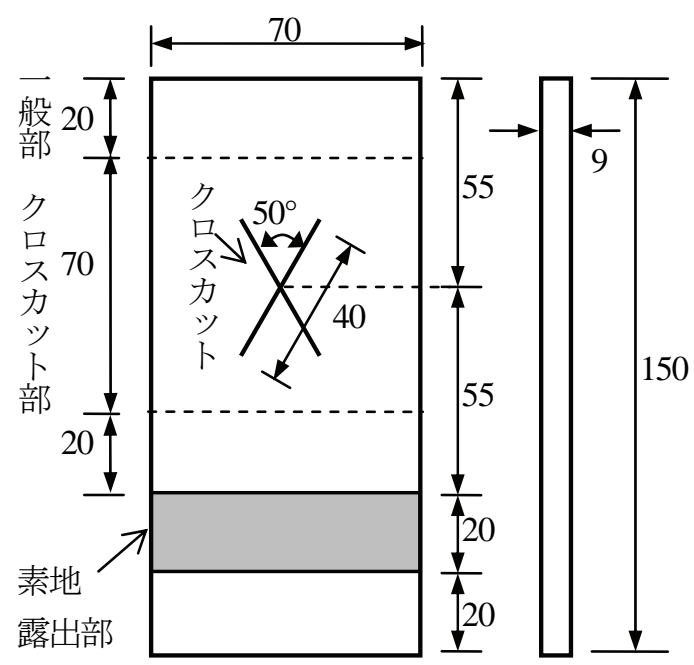

図-2 供試体寸法(単位 : mm)

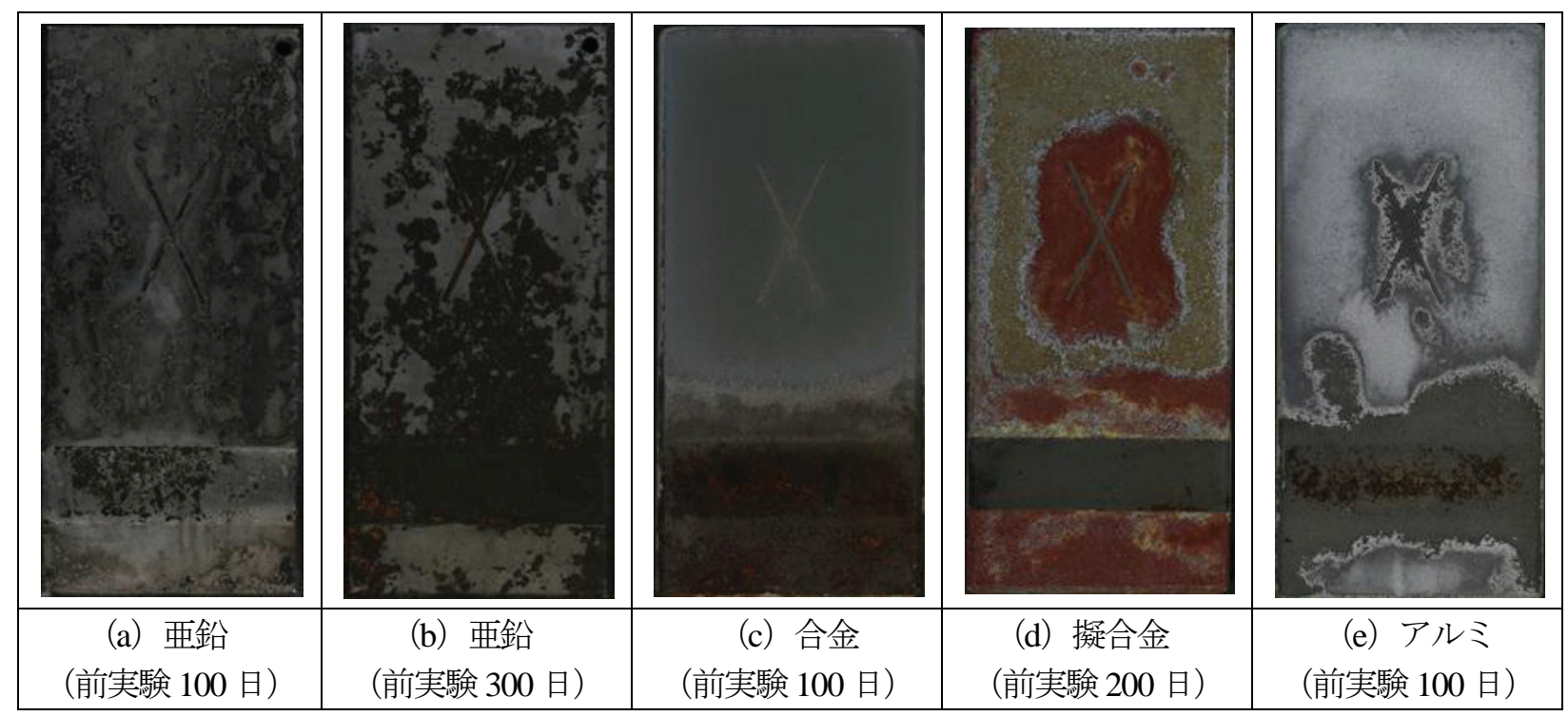

図-3＼cjkstart前実験による白さび除去後の供試体 
表-2 残存金属皮膜厚(単位: $\mu \mathrm{m}$ )

\begin{tabular}{|c|c|c|c|c|c|c|c|c|c|c|c|}
\hline \multirow{2}{*}{ 金属皮膜 } & \multirow{2}{*}{$\begin{array}{c}\text { 前実験 } \\
\text { 日数 }\end{array}$} & \multirow{2}{*}{$\begin{array}{c}\text { 供試体 } \\
\text { No. }\end{array}$} & \multicolumn{9}{|c|}{ 膜厚測定箇所 } \\
\hline & & & (1) & (2) & (3) & (4) & (5) & (6) & (7) & (8) & (9) \\
\hline \multirow{4}{*}{ 溶融亜鉛めつき } & 0 & 46 & 101 & 92 & 124 & 101 & 129 & 99 & 96 & 99 & 96 \\
\hline & 100 & 50 & 4 & 3 & 3 & 4 & 6 & 4 & 3 & 6 & 7 \\
\hline & 200 & 52 & 4 & 6 & 3 & 4 & 7 & 3 & 4 & 4 & 7 \\
\hline & 300 & 55 & 4 & 15 & 3 & 11 & 9 & 5 & 3 & 17 & 4 \\
\hline \multirow{4}{*}{ 亜鉛アルミ合金溶射 } & 0 & 61 & 120 & 122 & 112 & 99 & 99 & 96 & 103 & 107 & 103 \\
\hline & 100 & 64 & 29 & 54 & 78 & 33 & 43 & 49 & 6 & 13 & 10 \\
\hline & 200 & 67 & 5 & 14 & 19 & 10 & 18 & 23 & 18 & 19 & 18 \\
\hline & 300 & 70 & 19 & 28 & 13 & 18 & 15 & 15 & 17 & 11 & 13 \\
\hline \multirow{4}{*}{ 亜鉛アルミ擬合金溶射 } & 0 & 76 & 178 & 175 & 210 & 136 & 130 & 172 & 180 & 161 & 194 \\
\hline & 100 & 79 & 213 & 193 & 206 & 210 & 203 & 213 & 227 & 206 & 208 \\
\hline & 200 & 82 & 185 & 188 & 179 & 195 & 7 & 166 & 197 & 8 & 197 \\
\hline & 300 & 85 & 5 & 4 & 8 & 9 & 12 & 13 & 6 & 7 & 5 \\
\hline \multirow{4}{*}{ アルミ溶射 } & 0 & 91 & 108 & 126 & 105 & 134 & 134 & 123 & 145 & 109 & 132 \\
\hline & 100 & 94 & 107 & 91 & 109 & 113 & 91 & 123 & 23 & 107 & 82 \\
\hline & 200 & 103 & 102 & 123 & 133 & 109 & 14 & 133 & 19 & 26 & 26 \\
\hline & 300 & 100 & 109 & 17 & 18 & 20 & 32 & 26 & 46 & 37 & 30 \\
\hline
\end{tabular}

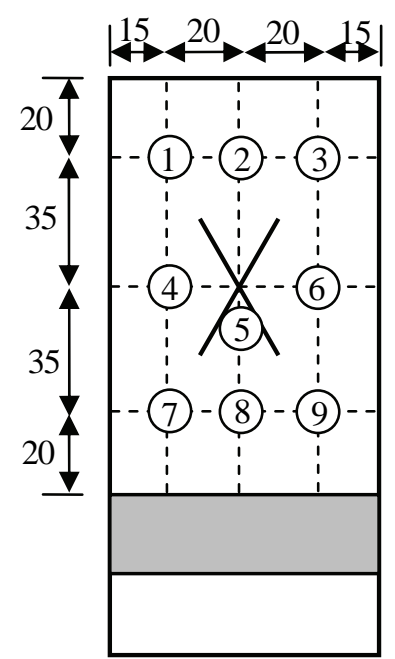

図-4 膜厚測定箇所(単位 : mm)

$10 \mathrm{~mm}$ 程度の区間においては，残存金属皮膜が多く，そ れより上部の金属皮膜の消耗が激しくなっていた．また， 素地露出部下部の金属皮膜の消耗が激しく, 残存皮膜が 少ないのに対し，一般部は金属皮膜が多く残存していた. アルミ溶射

アルミニウム溶射被覆鋼板を 100 日間劣化させた供試 体（以下，アルミ前実験 100 日供試体と称す）では，素 地露出部上部の素地露出部との境界から $1 \mathrm{~mm}$ 程度の区 間においては，鋼板素地の腐食が生じていなかったが， それより上部では, 鋼板素地が若干腐食していた. また, クロスカット部では, 直近から順に, 残存皮膜が多い区 間，少ない区間，多い区間という残存皮膜の濃淡が生じ
表-3 Rc-I 塗装系 ${ }^{12)}$

\begin{tabular}{|c|c|c|}
\hline 塗装工程 & 塗料名 & $\begin{array}{c}\text { 使用量 } \\
\left(\mathrm{g} / \mathrm{m}^{2}\right)\end{array}$ \\
\hline 素地調整 & \multicolumn{2}{|l|}{1 種 } \\
\hline 下塗り & 有機ジンクリッチペイント & 600 \\
\hline I & $\begin{array}{c}\text { 弱溶剤形変性エポキシ樹脂 } \\
\text { 塗料下塗 }\end{array}$ & 240 \\
\hline "I & "I & 240 \\
\hline 中塗り & $\begin{array}{c}\text { 弱溶剤形ふ心つ素樹脂 } \\
\text { 塗料用中塗 }\end{array}$ & 170 \\
\hline 上塗り & $\begin{array}{c}\text { 弱溶剤形出つ素樹脂 } \\
\text { 塗料上塗 }\end{array}$ & 140 \\
\hline
\end{tabular}

ていた.

全ての供試体で素地露出部と一般部の境界線の直近に おいて，金属皮膜の消耗が少ない区間，もしくは鋼板素 地が腐食していない区間が存在していた。この区間の幅 は $1 \mathrm{~mm}$ から $10 \mathrm{~mm}$ 程度であり, 金属皮膜の種類別には, アルミう合金<擬合金う亜鉛であった．また，覀鉛めっ きでは，一般部を含むほぼ全域から金属皮膜の消耗が進 行しているのに対し，合金，擬合金，およびアルミの金 属被覆は，欠陥部周囲から広がるように金属皮膜の消耗 が進行しており，一般部の金属皮膜の消耗は，あまり顕 著ではなかった. 
表-4 本実験に用いる供試体数

\begin{tabular}{|c|c|c|c|c|c|c|c|}
\hline \multicolumn{2}{|l|}{ 防食処理 } & \multirow{2}{*}{ 呼称 } & \multicolumn{4}{|c|}{ 金属被覆劣化日数（前実験日数） } & \multirow{2}{*}{ 計 } \\
\hline 残存金属被覆 & 塗装系 & & 0 & 100 & 200 & 300 & \\
\hline 溶融冓鉛めつき & Rc-I & 亜鉛 & 2 & $2+2 *$ & 3 & 3 & 12 \\
\hline 亜鉛アルミ合金溶射 & Rc-I & 合金 & 2 & 3 & 3 & 3 & 11 \\
\hline 亜鉛アルミ擬合金溶射 & Rc-I & 擬合金 & 2 & 3 & 3 & 3 & 11 \\
\hline アルミ溶射 & Rc-I & アルミ & 2 & 3 & 3 & 3 & 11 \\
\hline なし & Rc-I & 新規塗装 & & & & & 3 \\
\hline & & $*$ 塩水唯 & 促 & 儿試 & & & 計 48 \\
\hline
\end{tabular}

白さびを除去した前実験 100 日，200 日，および 300 日終了後の供試体に前実験 0 日（溶射後劣化させず塗装 した供試体)の新規金属被覆鋼板を加え, アルミナ（\#80） を用いて, 活膜を残すようにスイープブラストによって, 塗装前の素地調整を行った. 表-2 に図-4 の計測地点にお いて測定した残存金属皮膜の膜厚を供試体の種類ごとに 示す．表-2には，各条件 1 体の計測結果しか示していな いが, 同一条件の他の供試体も, ほぼ同じ状態であった.

本実験の供試体としては，上述したブラスト後に，表 $-3^{12)}$ に示す Rc-I 塗装系で塗装補修を行ったものを用いた。 また，比較のために，新規鋼板に Rc-I 塗装系で塗装を施 した供試体（以下，新規塗装供試体と称寸）も 3 体作製 した．補修に用いた Rc-I 塗装系は通常の塗装系の塗替え に用いられるものであるが，金属溶射の補修にも実際に

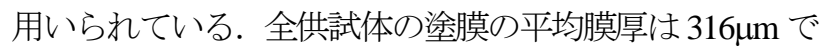
あり，標準偏差は $33 \mu \mathrm{m}$ であった.

本実験に用いた供試体一覧を表-4に示寸，供試体は合 計で 48 体用いた．ただし，表-4 に示寸亜鉛前実験 100 日供試体の 3 体のうち 1 体は，計測のために破壊試験を 行ったため, 2 体しか本実験の供試体として準備すること が出来なかった. そのため表-4の (2*) で示したように, 文献 6)において使用され，塩水噴霧複合サイクル試験に より劣化させた供試体を同様に補修して 2 体加えた．金 属皮膜の平均残存膜厚は, $25 \mu \mathrm{m}$ 程度と, 酸性雨噴霧によ り劣化させた供試体よりも平均的に厚く残存していた。

\section{（4）計測項目}

本実験で行う計測事項は以下の通りである.

a) 写真撮影 : 外観変化を観察するため, 供試体表面の塩 分は可能な限り除去した後, 写真撮影を 25 日ごとに 行った.

b) 表面形状: レーザー深度計 (KEYENCE 社製LE-4010) を用いて，100 日ごとに供試体表面全面に対して行っ た. 測定間隔は縦横 $0.3 \mathrm{~mm}$ とした.

c) 光沢度 : 100 日ごとに各供試体につき一般部で 3 点ず つ計測した。 d) インピーダンス:インピーダンス測定器 LCR ハイテ スタ（日置電気株式会社製）を用いて, 交流抵抗值(Rp), 静電容量值(Cp), および損失係数(D)の值を, 本実験の 前後で測定した.

e) 付着力:クロスカット上部における鋼板素地一金属 皮膜間および金属皮膜一塗膜間での付着力を, 本実 験の前後に測定した。

f) 腐食生成物の成分分析 : 欠陥部や一般部に生成された 腐食生成物の成分分析を X 線回折装置(島津製作所製) を用いて行った。

g) 金属皮膜の膜厚減少量 : 塗膜を塗膜剥離剤(インバイ ロワン，山一化学工業株式会社製）を用いて除去した 後, 図-4 で示した 9 点の残存金属皮膜の膜厚を測定し, 膜厚減少量を求めた.

\section{3. 実験結果および考察}

\section{（1）経時変化の外観観察}

前実験 0 日と前実験 300 日供試体を用いた本実験 300 日経過時の外観を図-5 と図-6 に示す.

新規塗装供試体

新規塗装供試体では，本実験 100 日段階でクロスカッ 卜と素地露出部において赤さびが発錆している. 300 日段 階では, 素地露出部のさびが膨れ上がり, また，素地露 出部とクロスカットに接する塗膜が膨れ上がっている. 亜鉛供試体

本実験 100 日段階で，前実験 0 日供試体では，素地露 出部に赤さび，クロスカットの全域に白さびが発錆して おり，クロスカットは白さびで覆われている，その他の 前実験 100 日〜300 日供試体では, クロスカットと素地露 出部は赤さびが発錆している.

本実験 200 日段階では，前実験 0 日供試体では，素地 露出部に一部白さびの発錆が見られるが，その他の前実 験 100 日〜300 日供試体では, 新規塗装供試体と同様に, 素地露出部のさびが膨れている.

本実験 300 日段階では, 前実験 0 日供試体のクロスカ 


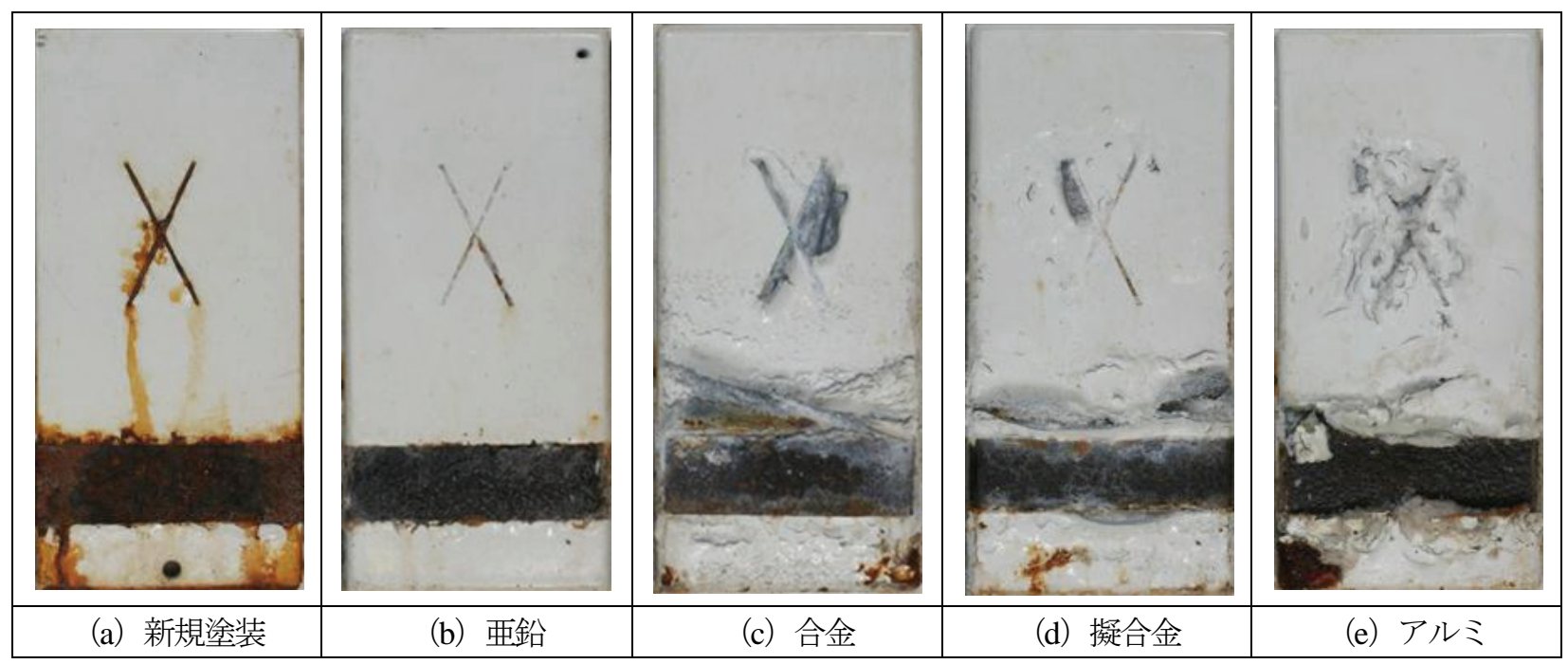

図-5 本実験 300 日経過時の供試体外観（前実験 0 日）

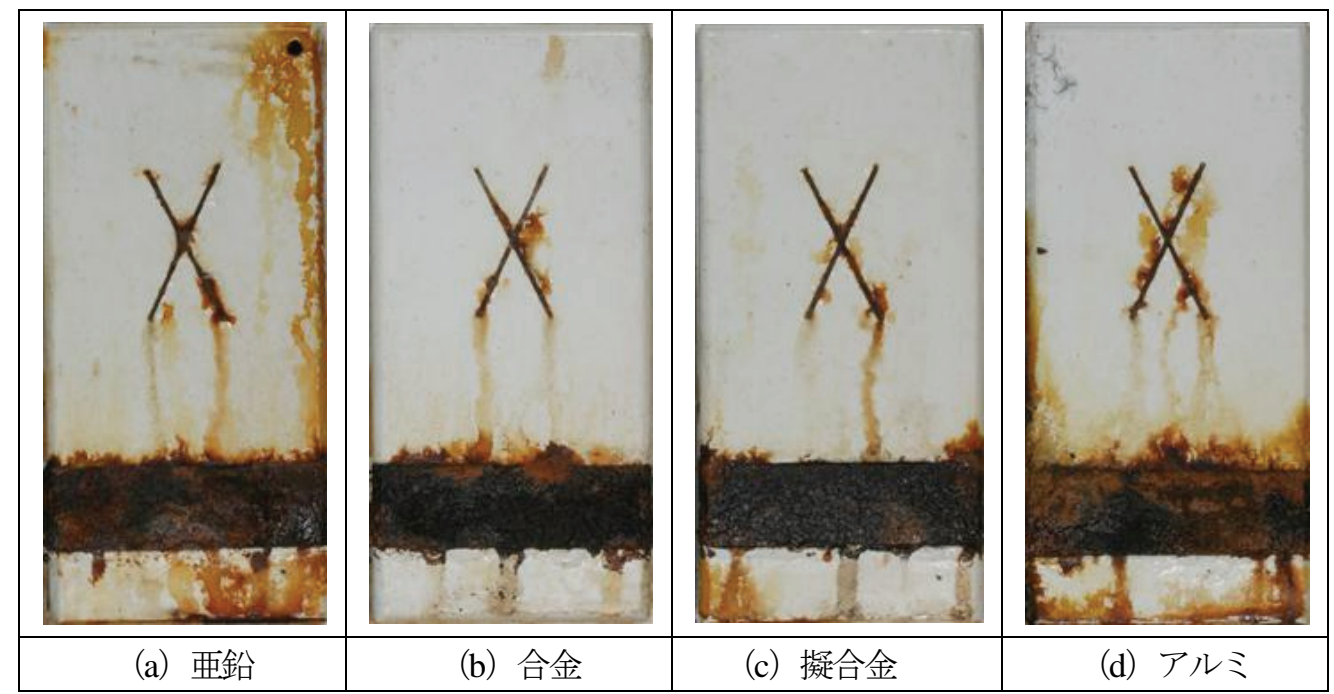

図-6 本実験 300 日経過時の供試体外観（前実験 300 日）

ット部にも一部赤さびが発錆している．また，全ての亜 鉛供試体において, クロスカットと素地露出部の直近で 塗膜が膨れている.

供試体欠損のために用いた前実験で塩水噴霧により劣 化させた供試体の外観変化は，酸性雨噴霧により劣化さ せた供試体と，ほぼ同様の経時変化であったため，前実 験で塩水噴霧により劣化させた供試体を代用して問題な いとした.

\section{合金供試体}

本実験 100 日段階では，前実験 0 日供試体で，素地露 出部の一部, クロスカットの全域に白さびが発錆してい る. 前実験 100 日供試体でもクロスカットの一部に白さ びが発錆している. 前実験 200 日，300 日供試体では，素 地露出部とクロスカットの全域に赤さびが発錆している. 本実験 200 日段階では，前実験 0 日供試体で，素地露 出部上部およびクロスカット部から比較的大きな面積の 塗膜が剥離するピーリングや，小面積でりん片状に剥離
するフレーキングが生じている. 素地露出部上部に生じ たフレーキングは, 素地露出部直近ではなく, 端部から $3 \mathrm{~mm} \sim 10 \mathrm{~mm}$ 程度の幅をおいて生じており, 素地露出部 と反対側が開口している. 剥離が生じるまでの幅は, 前 実験の白さび除去後に亜鉛や合金の皮膜が多く残存して いた幅とほぼ同一の長さである. 素地露出部下部におい ても，皮膚下の血管のように，塗膜が線状に膨れていた り，ピーリングが生じている． 線状の膨れ上がりの位置 は，素地露出部上部でフレーキングが生じている地点と 同様に, 素地露出部より $3 \mathrm{~mm}$ から $10 \mathrm{~mm}$ 程度離れた位置 である。

本実験 300 日段階では, 前実験 0 日供試体で, クロス カットより下部の全域でピーリングやフレーキングとい った塗膜の剥離が生じている. その他の前実験 100 日〜 300 日供試体は，本実験 200 日，300 日段階で，新規塗装 供試体とほぼ同様の外観を呈している. 


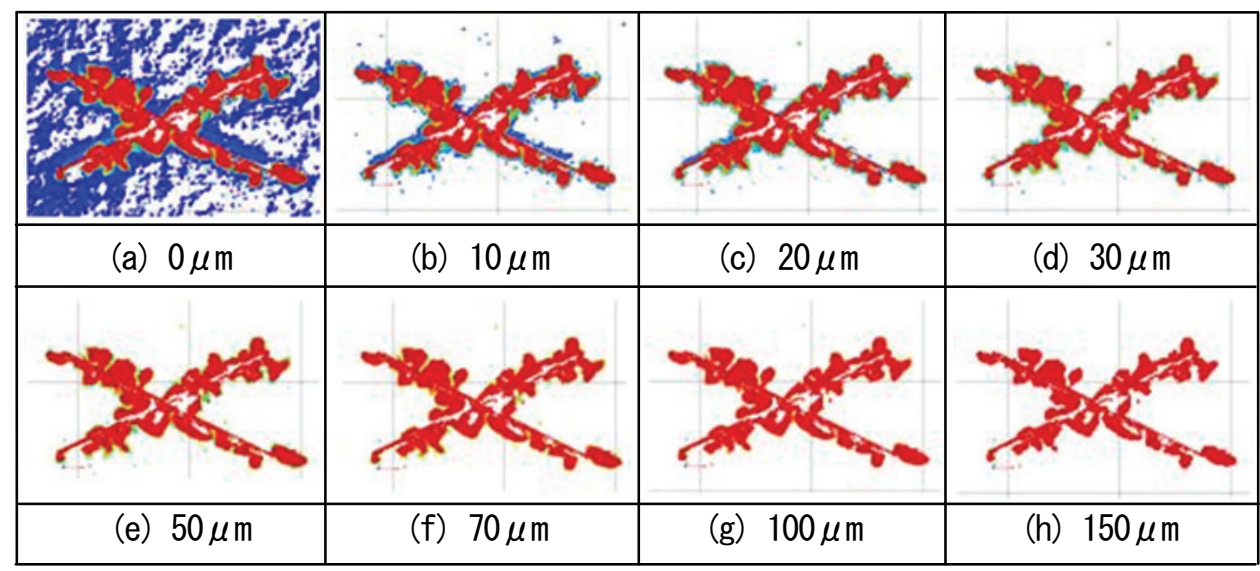

図-7 閾值ごとのふくれ面積

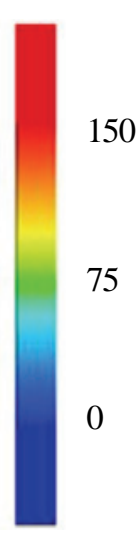

単位 : $\mu \mathrm{m}$

\section{擬合金供試体}

本実験 100 日段階における，前実験 0 日供試体で，素 地露出部の境界に線状に白さびが発錆するという特徵以 外は，合金供試体の経時変化とほぼ同じである.

\section{アルミ供試体}

本実験 100 日段階では，クロスカットにおいて，前実 験 0 日供試体でほぼ全域，前実験 100 日供試体の一部で 白さびが発錆している，また，素地露出部においても， 一部白さびが発錆している. 前実験 200 日，300 日供試体 では，クロスカットと素地露出部に若干の白さびが発錆 している.

本実験 200 日段階では，前実験 0 日，100日，および 200 日供試体において，クロスカットより $1 \mathrm{~mm} \sim 15 \mathrm{~mm}$ 程度の幅をおいた地点からフレーキングが生じている。 開口の向きは，クロスカットに対して反対側である。ま た, 前実験 0 日供試体では, 素地露出部の端部から $1 \mathrm{~mm}$ 〜 $5 \mathrm{~mm}$ 程度の幅をおいた地点からも同様に，フレーキン グが生じている. フレーキングが生じる地点までの幅は, 合金や擬合金に比べると小さい.

本実験 300 日段階では，前実験 0 日，100日，および 200 日供試体でのクロスカット周囲と, 前実験 0 日供試体 の素地露出部近傍のフレーキングが進展し, 中程度の面 積の剥離であるスケーリングにまで進展しており, クロ スカットより下部は全域で塗膜の剥離が生じている．前 実験 300 日供試体の外観の経時変化は, 新規塗装供試体 の外観変化とほぼ同じである.

\section{（2）ふくれ面積}

環境促進実験の時間経過に従って，クロスカット部や 素地露出部から腐食が広がり, 塗膜にふくれが生じてい る. 本研究では, レーザー深度計を用いて計測した供試 体の表面形状データから，塗膜のふくれが発生している 面積を算定し，塗膜劣化の定量的評価指標とする．本実 験では残存金属皮膜の上に塗装で補修を行って供試体を

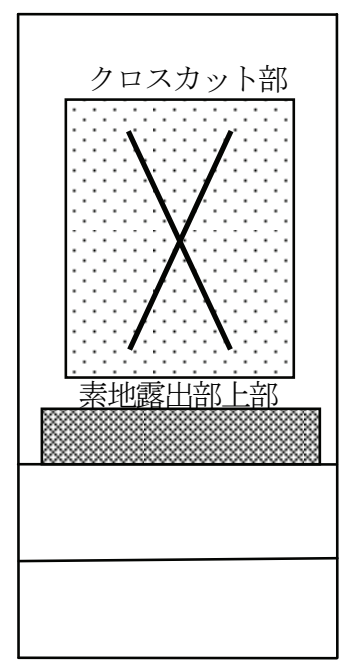

図-8 対象部分（網掛け部）

作製したため，本実験開始前の初期状態において目視で 確認できるほど表面に凹凸が発生している場合もある. そこで, 本実験 100 日，200 日，および300 日経過時にお ける表面形状データから初期計測データを引いたものを 用いてふくれ面積を判定する.

ふくれを判定する闇值によるふくれ面積の違いを図-7 に示す. 図中では，ふくれと判定された地点をふくれの 高さに応じて着色している. 本研究では，ふくれ面積の 算定による誤差が含まれなくなり, 計測・補正誤差が許 容範囲を下回る最低值である $20 \mu \mathrm{m}$ 以上をふくれと判定 する. 図-8 に示寸対象範囲に従い，1)クロスカット部, 2)素地露出部上部のふくれ面積を経過日数ごとに算出し たものを表-5に示寸．また，本実験 300 日経過時のふく れ面積と平均残存膜厚との関係を図-9 に示寸. 図中には, 比較のため, 実線で新規塗装供試体のふくれ面積を示す. 亜鉛供試体

前実験 100 日〜300 日供試体のふくれ面積は, クロスカ ット部, 素地露出部上部ともに, 新規塗装供試体とほぼ 同等である. 前実験 0 日供試体は, 実験全期間において, 


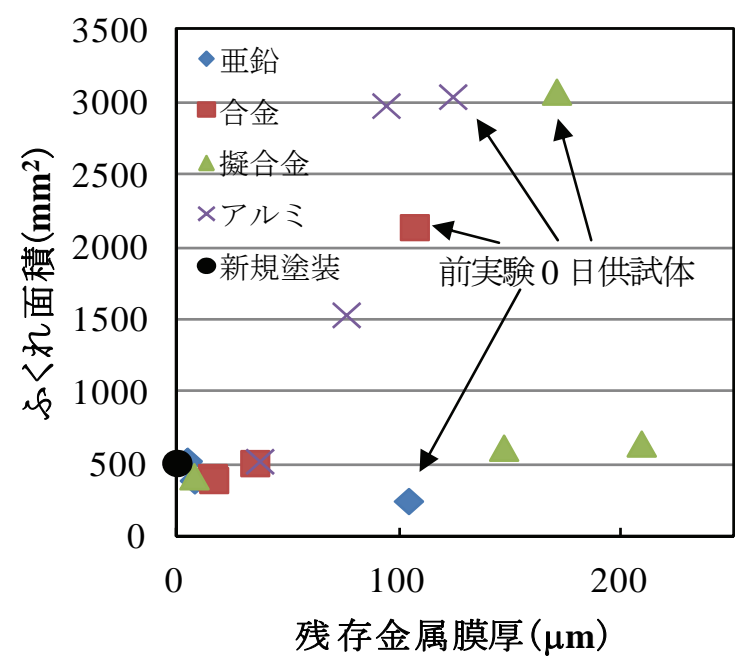

(a)クロスカット部

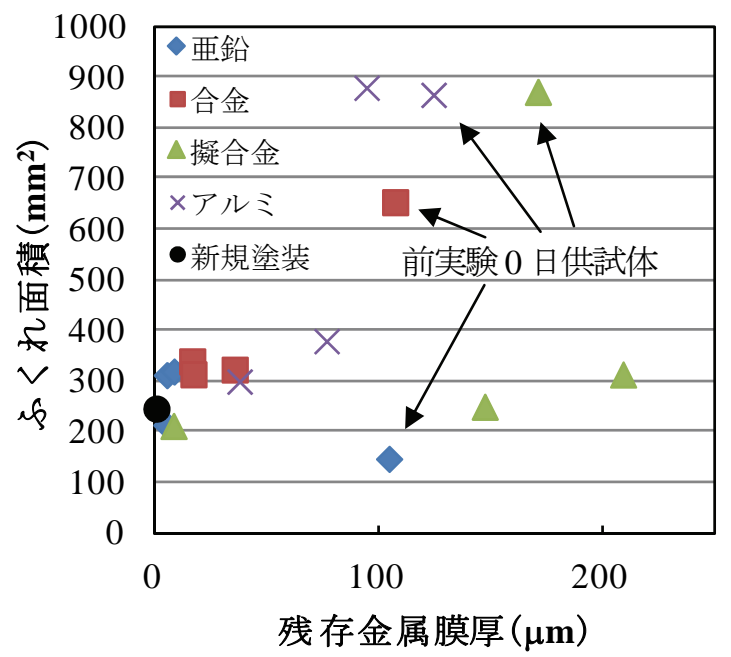

（b）素地露出部上部

図-9 塗膜のふくれ面積

新規塗装よりもふくれ面積が少なく, 本実験 300 日段階 では, 新規塗装供試体の $1 / 2$ 以下である. なお，塩水噴霧 により劣化させた供試体は，新規塗装供試体とほぼ同等 である.

\section{合金供試体}

前実験 0 日供試体のふくれ面積のみがクロスカット部, 素地露出部上部ともに新規塗装よりも格段に大きく，そ の他の前実験 100 日〜300 日供試体では, 新規塗装とほぼ 同等のふくれ面積である．なお，前実験 0 日供試体に関 しては, 素地露出部近傍を残して, 全域がふくくと判定 される. そのため, 本実験 300 日経過時のクロスカット 部のふくれは，素地露出部からのふくれとつながってお り，急激にふくれ面積が増大している.

\section{擬合金供試体}

擬合金前実験 100 日供試体は前実験 0 日供試体よりも 残存皮膜厚が厚いが，前実験 100 日供試体の方がふくれ 面積は小さい，そして，前実験 0 日供試体のふくれ面積 のタがクロスカット部，素地露出部ともに新規塗装供試 体よりも大きい，また，合金供試体同様に，擬合金前実 験 0 日供試体の本実験 300 日経過時の素地露出部上部に おけるふくれについても，対象面積のほぼ全域がふくれ と判定されたために，クロスカット部のふくれが，素地 露出部からのふくれとつながり，急激にふくれ面積が増 大している.

\section{アルミ供試体}

アルミ供試体におけるふくれ面積は，前実験 0 日〜20 日供試体がクロスカット部において，新規塗装供試体よ りも大きく, 前実験 0 日, 100 日供試体では, 素地露出部 においても新規塗装供試体よりもふくれ面積が大きい. ただし，前実験 300 日供試体のみは，新規塗装供試体と 表-5＼cjkstart経過日数ごとのふくれ面積

\begin{tabular}{|c|c|c|c|c|c|c|c|}
\hline \multirow{3}{*}{$\begin{array}{l}\text { 防食 } \\
\text { 処理 }\end{array}$} & \multirow{3}{*}{$\begin{array}{c}\text { 前実験 } \\
\text { 日数 }\end{array}$} & \multicolumn{3}{|c|}{ クロスカット部 } & \multicolumn{3}{|c|}{ 素地露出部上部 } \\
\hline & & \multicolumn{3}{|c|}{ 経過日数 } & \multicolumn{3}{|c|}{ 経過日数 } \\
\hline & & 100 & 200 & 300 & 100 & 200 & 300 \\
\hline \multirow{4}{*}{ 亜鉛 } & 0 & 75 & 119 & 257 & 5 & 67 & 149 \\
\hline & 100 & 76 & 168 & 533 & 3 & 71 & 216 \\
\hline & 200 & 91 & 189 & 536 & 28 & 70 & 315 \\
\hline & 300 & 108 & 201 & 400 & 26 & 105 & 322 \\
\hline \multirow{4}{*}{ 合金 } & 0 & & 193 & 2150 & 68 & 467 & 656 \\
\hline & 100 & 72 & 184 & 520 & 4 & 42 & 326 \\
\hline & 200 & 84 & 184 & 424 & 9 & 83 & 342 \\
\hline & 300 & 73 & 189 & 403 & 30 & 116 & 316 \\
\hline \multirow{4}{*}{ 擬合金 } & 0 & 154 & 458 & 3086 & 191 & 841 & 874 \\
\hline & 100 & 100 & 376 & 654 & 36 & 161 & 316 \\
\hline & 200 & 106 & 189 & 626 & 11 & 99 & 252 \\
\hline & 300 & 76 & 165 & 428 & 36 & 108 & 214 \\
\hline \multirow{4}{*}{ アルミ } & 0 & 277 & 462 & 3052 & 90 & 696 & 868 \\
\hline & 100 & 139 & 313 & 2990 & 12 & 89 & 882 \\
\hline & 200 & 146 & 258 & 1544 & 3 & 68 & 382 \\
\hline & 300 & 177 & $-^{*}$ & 533 & 21 & $-^{*}$ & 302 \\
\hline $\begin{array}{l}\text { 新規 } \\
\text { 塗装 }\end{array}$ & - & 89 & 246 & 521 & 27 & 108 & 249 \\
\hline
\end{tabular}

*データファイル破損

(単位 : $\mathrm{mm}^{2}$ )

ほぼ同等のふくれ面積である. 前実験 0,100 日供試体に 関しては，合金，擬合金前実験 0 日の供試体と同様に, 素地露出部からのふくれがクロスカット部のふくれとつ ながっている. また, 残存金属膜厚に着目寸ると, 残存 金属膜厚が厚いほどふくれ面積は増大しており，相関関 
係が見られる。

これらのことから，亜鉛めつきの金属皮膜は，活膜を 補修塗装時に残しておいても，塗膜の防食性能に悪影響 を及ぼさず，場合によっては塗膜の劣化を遅延させる効 果も期待できるが，合金，擬合金，アルミ溶射の残存金 属皮膜は，塗膜の防食性能を低下させる．特に，前実験 0 日供試体のように，金属皮膜が残存している地点に鋼板 素地まで達するような傷がある場合は，新規塗装のみの 劣化に比へ，塗膜が膨れ上がり剥離するため，早期に劣 化することがわかる.

\section{（3）塗膜の光沢度保持率}

塗膜の光沢度は，塗膜表面の劣化により平滑度が減少 していくことを表す劣化指標である．本実験では，塗膜 のふくれやわれが生じていない地点で，供試体ごとに 3 点ずつ計測し, 光沢度保持率 (残存光沢度/初期光沢度 $\times$ 100\%）を用いて評価する. 残存金属皮膜の種類によって, 最もふくれ面積の違いが顕著である前実験 0 日供試体の 光沢度保持率の経時変化を図-10に示す.横軸は本実験の 経過日数，縦軸は光沢度保持率である.

図-10に示すように, 塗膜の光沢度保持率の経時変化は, 残存金属皮膜の種類によらず，新規塗装供試体とほぼ同 じような值である．また，その他の前実験 100 日〜300 日供試体でも，同様の経時変化であり，残存金属皮膜の 種類や膜厚の違いによる光沢度の経時変化の差は見られ ない.

\section{（4）インピーダンス測定}

本実験の前後で，各金属皮膜を下地に有する前実験 0 日供試体と新規塗装供試体の一般部において，0.2，0.5， 1.0, および2.0kHz に対する a)交流抵抗值, b)電気容量值, および c)損失係数の測定を行った. なお，本実験 0 日段 階の擬合金前実験 0 日供試体については，供試体が欠損 していたため，塩水噴霧促進実験を 100 日行った供試体 のうち，金属皮膜の残存膜厚が厚い供試体を前実験 0 日 供試体の代用として計測した. 図-11に例として, 周波数 $0.2 \mathrm{kHz}$ における交流抵抗值の測定結果を示す。なお，横 軸は本実験の経過日数であり, 縦軸は交流抵抗值である.

図-11 に示すように, 供試体の一般部において, 新規塗 装では，交流抵抗值の変化から判断する限り性能が低下 することはないが，金属皮膜を下地に有する供試体にお いては，塗膜の劣化が進行していると考えられる．すな わち，若干の劣化ではあるが，腐食電流が流れやすくな るため, 塗膜下腐食が進行しやすくなる傾向があると言 える.しかし，劣化後においても，評価項目ごとに電気 事業連合会 ${ }^{13)}$ の評価基準と関西ペイント株式会社の資 料 ${ }^{14)}$ を用いて判定した場合，全供試体で塗膜の健全性は 保たれていた. また，インピーダンス(Z)の周期依存性に

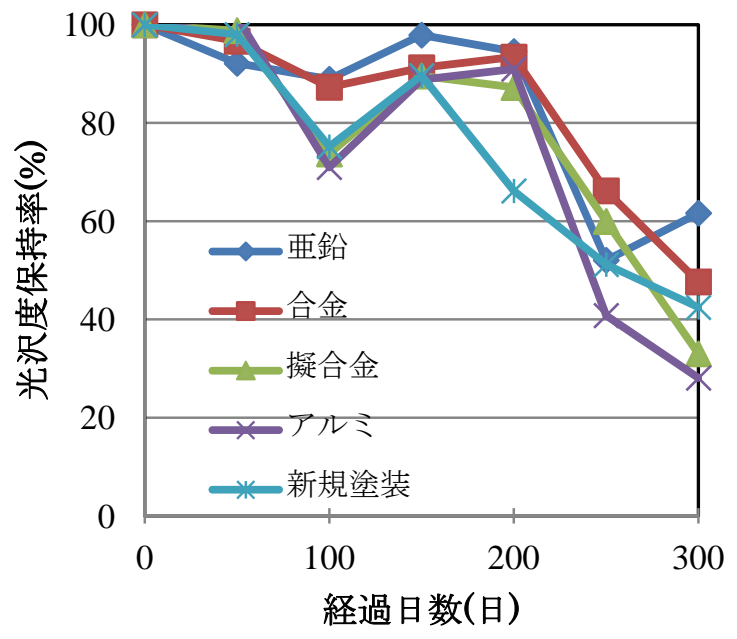

図-10 光沢度保持率の経時変化

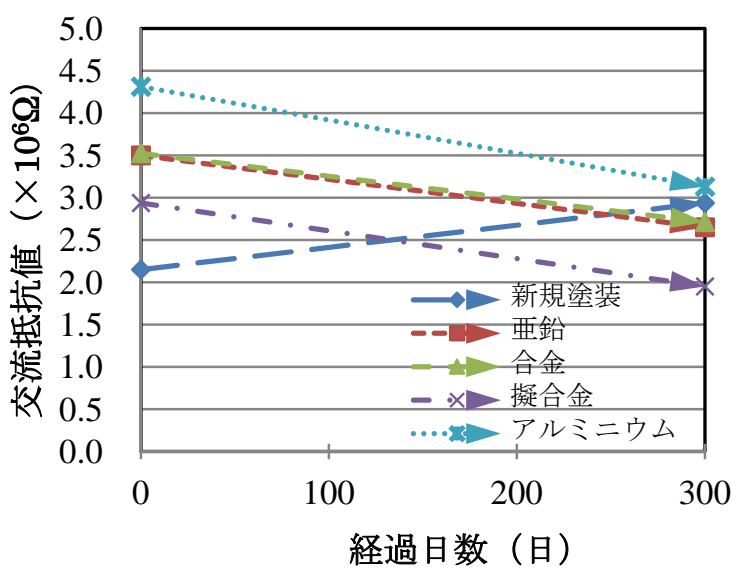

図-11 交流抵抗值(0.2kHz)

ついては，全供試体で測定を行ったが確認できなかった.

\section{（5）付着力}

塗膜の良好な付着は塗膜下への水分などの侵入を防ぎ， さびの発生および進展を遅らせる，また，同様に金属皮 膜についても，鋼板素地に対する環境遮断効果が期待さ れているため，防食性能の観点から環境促進実験後も良 好な付着力が，鋼板素地一金属皮膜間および金属皮膜— 塗装膜間で確保されている必要がある。本研究では，本 実験前と本実験後の一般部において，塗膜を層ごとにサ ンドペーパーによって除去することにより，各層間での 付着力の測定を行い，本実験による付着力への影響を検 討する. なお，インピーダンス測定と同様に，本実験 0 日の擬合金前実験 0 日供試体については，塩水噴霧促進 実験を 100 日行った供試体のうち，金属皮膜の残存膜厚 が厚い供試体を前実験 0 日供試体の代用として計測した. 前実験 0 日供試体の塗膜の除去段階ごとの付着力を表 -6 に示す. 付着力が上層の塗膜よりも小さくなる場合が あるのは，付着力測定時に，塗膜の各層内での結びつき 
が弱いためにドリー (試験円筒) 全面で塗膜が剥離せず, 一部分のみが剥離し，局所的な付着力を測定したためで ある。

新規塗装供試体と比較しても，残存金属皮膜の種類に よらず，一般部において付着力は低下していない.

擬合金供試体は下塗りと金属被覆間の付着力が強く, 中塗り除去後の測定において，一気に粗面形成剤の層か ら剥離した．溶融亜鉛めっき皮膜と合金溶射皮膜につい ては，金属皮膜が剥離することはなかった。

\section{（6）腐食生成物}

\section{a）塗膜下の腐食状況}

本実験終了後, 金属皮膜を下地に有する各前実験 0 日 供試体の塗膜を手作業によって簡易除去した. 本実験 300 日後のアルミ前実験 0 日供試体において，塗膜を除去後 で腐食生成物を除去する前の外観を図-12 に示寸．また， 腐食生成物を塩化ビニルブラシで除去した後の金属皮膜

表-6 付着力測定結果（前実験 0 日供試体）

\begin{tabular}{|c|l|r|r|r|c|}
\hline $\begin{array}{c}\text { 本実験 } \\
\text { 日数(日) }\end{array}$ & 防食方法 & 上塗 & 中塗 & 下塗 & $\begin{array}{c}\text { 金属 } \\
\text { 皮膜 }\end{array}$ \\
\hline \multirow{4}{*}{0} & 新規塗装 & 2.0 & 3.8 & 5.6 & - \\
\cline { 2 - 6 } & 亜鉛 & 2.5 & 3.5 & 3.4 & - \\
\cline { 2 - 6 } & 合金 & 3.1 & 3.9 & 4.5 & - \\
\cline { 2 - 6 } & 擬合金 & 2.8 & 2.5 & 4.8 & 5.0 \\
\cline { 2 - 6 } & アルミ & 3.7 & 4.0 & 4.0 & 4.9 \\
\hline \multirow{4}{*}{300} & 新規塗装 & 3.8 & 6.5 & 6.5 & - \\
\cline { 2 - 6 } & 亜鉛 & 3.6 & 6.0 & 5.4 & - \\
\cline { 2 - 6 } & 合金 & 5.4 & 4.6 & 4.6 & 4.9 \\
\cline { 2 - 6 } & 擬合金 & 2.9 & 4.1 & - & 4.2 \\
\cline { 2 - 6 } & アルミ & 5.2 & 3.4 & - & 4.1 \\
\hline
\end{tabular}

単位: MPa
ごとの供試体外観を図-13 に示す，なお，亜鉛前実験 0 日供試体については，素地露出部上部の塗膜を金属光沢 が見えるまでサンドペーパーによって除去した．なお，

図-13 の供試体上部の円形は, 付着力測定のドリーである.

図-12 に示寸ように, パウダー状で白色の生成物が多量 に塗膜下で生成されていた. 亜鉛前実験 0 日供試体では, そのような生成物はなかったが，合金前実験 0 日供試体 と擬合金前実験 0 日供試体ではアルミ前実験 0 日供試体 と同様にパウダー状の生成物が生じており，その量はア ルミ前実験 0 日供試体で最多であった.

要鉛前実験 0 日供試体については, 塗膜下での鋼板素 地の赤さびも亜鉛の白さびも全く見られなかった. しか しながら，素地露出部との境界に黒色の部分が存在して おり，この黒色の面積の多、地点においては，塗膜のふ くれが見られたため，この黒色部は亜鉛の腐食生成物と 考えられる.

合金前実験 0 日供試体については，素地露出部下部の 塗膜も手作業によって剥離できたため除去した．その結 果, 素地露出部下部および上部の一部では, 鋼板素地の 赤さびを確認した。 また, 素地露出部直近では, 固く白 色の生成物の塊が存在し，この生成物が隆起していた. この固く白色の生成物は, クロスカット近傍にも存在し ており, 久陥部に多く存在していた. また, クロスカッ 卜を中心として，リング状の腐食生成物の濃淡が生じて いた.

擬合金前実験 0 日供試体に関しては，合金とほぼ同様 の現象が生じているが，粗面形成材が一部確認できる程 度で，赤さびは発錆していなかった。

アルミ前実験 0 日供試体については，久陷部周囲に固 い生成物が隆起して存在していた，また，赤さびは，そ の固い生成物が少なくなった地点から一般部全域に広が って分布していた.

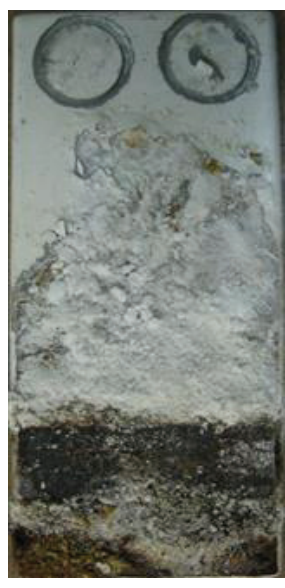

図-12 塗装膜下の腐食 生成物

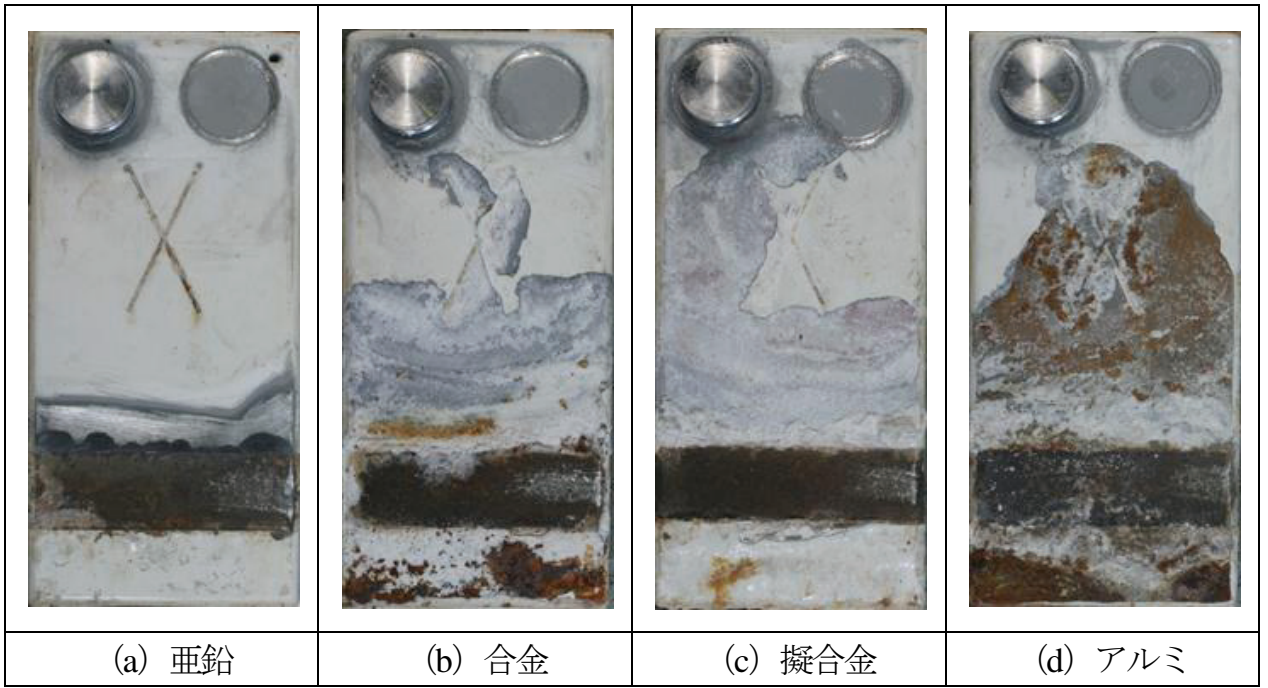

図-13 塗装膜の簡易除去後（前実験 0 日供試体） 


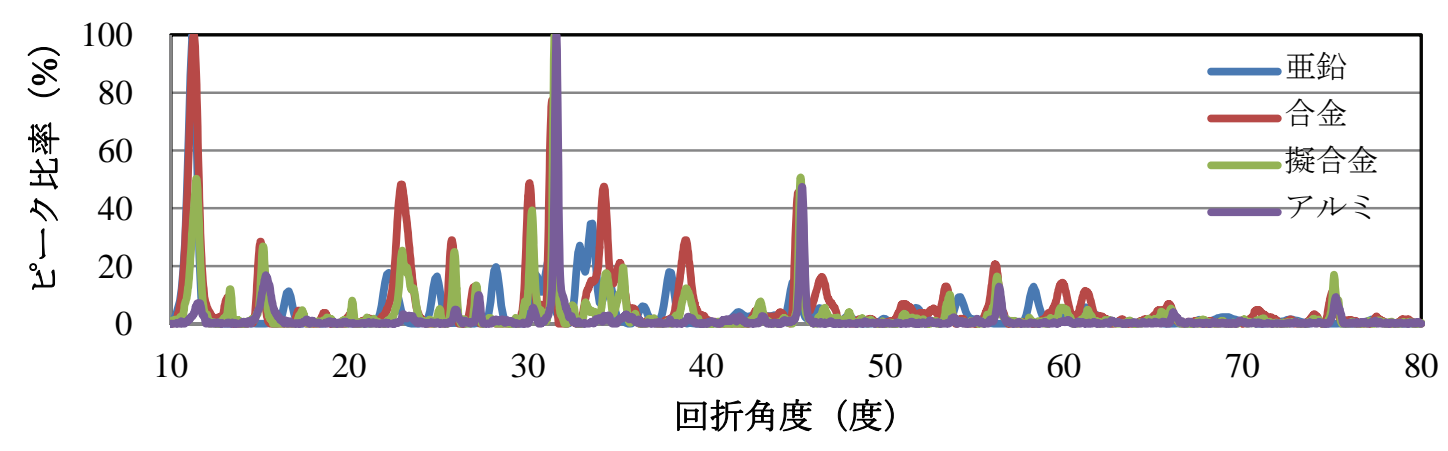

図-14 XRD 結果

表-7 本実験の膜厚減少量（単位： $\mu \mathrm{m})$

\begin{tabular}{|c|c|c|c|c|c|}
\hline & \multicolumn{4}{|c|}{ 測定箇所 } \\
\hline & & (7) & (8) & (9) & 平均 \\
\hline \multirow{3}{*}{ 亜鉛 } & 初期 & 100 & 99 & 97 & 99 \\
\hline & 実験後 & 82 & 76 & 77 & 78 \\
\hline & 膜厚減少量 & 18 & 23 & 20 & 20 \\
\hline \multirow{3}{*}{ 合金 } & 初期 & 115 & 123 & 113 & 117 \\
\hline & 実験後 & 30 & 18 & 15 & 21 \\
\hline & 膜厚減少量 & 85 & 105 & 98 & 96 \\
\hline \multirow{3}{*}{ 擬合金 } & 初期 & 197 & 212 & 225 & 211 \\
\hline & 実験後 & 98 & 107 & 101 & 102 \\
\hline & 膜厚減少量 & 99 & 105 & 124 & 109 \\
\hline \multirow{3}{*}{ アルミ } & 初期 & 109 & 108 & 104 & 107 \\
\hline & 実験後 & 9 & 14 & 7 & 10 \\
\hline & 膜厚減少量 & 100 & 94 & 97 & 97 \\
\hline
\end{tabular}

\section{b）生成物の成分分析}

各前実験 0 日供試体に生じた塗膜下生成物の成分分析 をXRDにより行った，その結果を図-14に示す。横軸は 回折角度，縦軸はピーク比率である.

$\mathrm{X}$ 線回析による分析の結果，素地露出部境界で見られ た亜鉛供試体の黒色の腐食生成物は，サイモンコライト

$\left(\mathrm{Zn}_{5}(\mathrm{OH})_{8} \mathrm{Cl}_{2} \cdot \mathrm{H}_{2} \mathrm{O}\right)$ であると同定した. このサイモン コライトは, アニオン交換能をもつとされている. また, 合金と擬合金の塗膜下生成物は，ピーク值の出現角度が 類似しており，両者の塗膜下生成物はほぼ同じと思われ る，そして，合金，擬合金，およびアルミの塗膜下生成

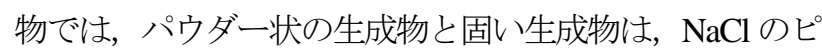
一クが確認できた。これは，塗膜の久陥部から流入した 塩水が，塗膜下で凝固したと考えられる. 合金, 擬合金, およびアルミでは， $\mathrm{NaCl}$ 以外と思われるピークも確認で き，特に，合金と擬合金で測定したピークは，亜鉛で生 成していたサイモンコライトのピークと比較的一致して いたが，物質の同定には至らなかった。
表-8 前実験の膜厚減少量 (単位 : $\mu \mathrm{m})$

\begin{tabular}{|c|c|c|c|c|c|}
\hline & \multicolumn{4}{|c|}{ 測定箇所 } \\
\hline & & (7) & (8) & (9) & 平均 \\
\hline \multirow{3}{*}{ 亜鉛 } & 初期 & 90 & 90 & 83 & 88 \\
\hline & 実験後 & 15 & 17 & 1 & 11 \\
\hline & 膜厚減少量 & 75 & 73 & 82 & 76 \\
\hline \multirow{3}{*}{ 合金 } & 初期 & 130 & 119 & 125 & 125 \\
\hline & 実験後 & 25 & 24 & 20 & 23 \\
\hline & 膜厚減少量 & 105 & 95 & 105 & 102 \\
\hline \multirow{3}{*}{ 擬合金 } & 初期 & 251 & 220 & 218 & 230 \\
\hline & 実験後 & 108 & 111 & 112 & 110 \\
\hline & 膜厚減少量 & 143 & 109 & 106 & 119 \\
\hline \multirow{3}{*}{ アルミ } & 初期 & 135 & 148 & 118 & 134 \\
\hline & 実験後 & 37 & 28 & 31 & 32 \\
\hline & 膜厚減少量 & 98 & 120 & 87 & 102 \\
\hline
\end{tabular}

\section{（7）金属皮膜の膜厚減少量}

各前実験 0 日供試体の塗装補修前に測定した初期金属 皮膜厚加，本実験終了後の塗膜を塗膜剥離剤を用いて 除去した後の金属皮膜の残存膜厚の測定結果を引くこと により，金属皮膜の膜厚減少量を求めた。最も塗膜の劣 化が激しく，金属皮膜の消耗も激しかったクロスカット 部と素地露出部の中間地点に位置する測定点(7), (8)およ び(9)の初期金属皮膜厚，実験後の残存金属皮膜厚，およ び金属皮膜減少厚を表-7 に示す。また，比較のため，前 実験 300 日供試体の前実験段階における測定結果を表-8 に示す. なお，表-7 に示す測定結果は，1 体ずつを付着 力測定により破壞したため，各供試体 1 体ずつの測定結 果であり，表-8については，3 体の平均值である.

表-7 と表-8 を比較すると, 塗装により亜鉛めつき皮膜 の膜厚減少量が大幅に減少しているのに対し，合金溶射 皮膜，擬合金溶射皮膜，およびアルミ溶射皮膜の膜厚減 少量は，塗装してもさほど変わらない結果となった。

前実験と本実験ともに，実験後の擬合金供試体の膜厚 が，他の供試体に比べ，厚い結果となっていた。これは, 
擬合金溶射特有の粗面形成剂の膜厚が加味されているた めである.

\section{(8) 考察}

前実験において，アルミニウム溶射の金属皮膜供試体 が素地露出部での白さびの発錆が最多であったことから， 酸性雨環境では，アルミニウムはガルバニック腐食を生 じやすいことが推定できる。このガルバニック腐食によ り，金属皮膜の塗膜下腐食反応が新規塗装の鋼板素地の 塗膜下腐食反応よりも激しくなり，防食性能が低下した と思われる，さらに，金属被覆が流出したことによる， 金属皮膜と塗膜の間のすきま腐食も塗膜下腐食が激しさ を増した要因であると考えられる。

しかしながら，残存皮膜の厚い擬合金前実験 100 日供 試体のふくれ面積が，新規塗装とほぼ同程度であったこ とから，擬合金の場合，鋼板素地が露出している位置の 周囲で金属皮膜が露出していなければ，ガルバニック腐 食が抑制され，著しい塗膜下腐食は生じにくくなると推 定される.

\section{4. 金属被覆による防食システムのライフサイクル コスト評価}

金属被覆による防食システムの維持管理段階について は，酸性雨環境に弱いことと，劣化した金属被覆の一般 性の高い補修方法が未確立であるというリスクが存在す る.このリスクを低減することを目的とし，ライフサイ クルコストを指標として，環境促進実験で，一定の防食 性能が確認された塗装による補修方法を適用した場合の 防食システムの合理性を検討する.

\section{（1）算定条件}

\section{a）設定環境}

設定環境としては，鋼橋のライフサイクルコストに関 する文献 ${ }^{15)}$ において示されている，一般環境，やや厳し い環境，および厳しい環境に対して，酸性雨の影響の有 無もそれぞれの環境に考慮した.

\section{b）防食システムを補修するまでの期間（防食寿命）}

新規金属被覆の防食寿命は，塩水噴霧複合サイクル実 験 ${ }^{16)}$ において, 赤さびが発生した時点における皮膜の減 少量を，皮膜の減耗速度で割ることによって，赤さび発 生までの期間を算出した. また, アルミ溶射に関しては, 防食作用が酸化被膜による遮断効果が主であり, 犠牲陽 極作用による防食効果を期待できない，そのため，一般 部においては金属皮膜の減耗はほとんど生じなくても, 傷などの欠陷部においては金属皮膜がガルバニック腐食 によって流出し, 遮断効果による防食作用を失い鋼板素 地の腐食が進行するため, 暴露試験結果 ${ }^{4}$ を参考に, 防食
表-9 一般環境での期間比率（酸性雨なし）

\begin{tabular}{|c|c|}
\hline 防食方法 & 期間比率 \\
\hline 溶融亜鉛めっき & 1.67 \\
\hline 亜鉛アルミ合金溶射 & 2.67 \\
\hline 亜鉛アルミ擬合金溶射 & 2.18 \\
\hline アルミ溶射 & 2.67 \\
\hline Rc-I 塗装 & 0.80 \\
\hline C-5 塗装 & 1.00 \\
\hline
\end{tabular}

表-10 厳しい環境での期間比率（酸性雨）

\begin{tabular}{|c|c|}
\hline 防食方法 & 期間比率 \\
\hline 溶融亜鉛めっき & 0.28 \\
\hline 亜鋁アルミ合金溶射 & 0.67 \\
\hline 亜鉛アルミ擬合金溶射 & 0.55 \\
\hline アルミ溶射 & 0.67 \\
\hline Rc-I 塗装 & 0.80 \\
\hline C-5 塗装 & 1.00 \\
\hline
\end{tabular}

表-11 防食費用

\begin{tabular}{|l|c|c|c|}
\hline & \multirow{2}{*}{ 新規 } & \multicolumn{2}{|c|}{ 更新 } \\
\cline { 3 - 4 } & & 塗装 & 溶射 \\
\hline $\begin{array}{l}\text { 溶融亜鉛 } \\
\text { めっき }\end{array}$ & 4820 & 10020 & - \\
\hline $\begin{array}{l}\text { 亜鉛アルミ } \\
\text { 合金溶射 }\end{array}$ & 14435 & 10020 & 17435 \\
\hline $\begin{array}{l}\text { 亜鉛アルミ } \\
\text { 擬合金溶射 }\end{array}$ & 14435 & 10020 & 17435 \\
\hline アルミ溶射 & 14435 & 12850 & 17435 \\
\hline Rc-I 塗装 & - & 10020 & - \\
\hline C-5 塗装 & 6580 & 10020 & - \\
\hline
\end{tabular}

単位: 円 $/ \mathrm{m}^{2}$

寿命は合金の防食寿命と同等とした.

また，前実験において，酸性雨条件下では，金属被覆 は防食機能の劣化が早まることが判明している．環境省

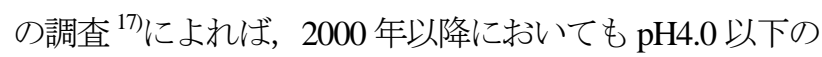
酸性雨が確認されており, また, 大陸由来の污染物質の 流入についても示唆されているため, 今後も持続的に酸 性雨の影響を考慮する必要がある，そこで，前実験の報 告のの中での, 塩水噴霧複合サイクル促進実験と酸性雨噴 霧複合サイクル促進実験の換算膜厚減少量の比較を参考 に，酸性雨環境では，防食寿命を覀鉛めっきで $1 / 3 ，$ 溶射 金属被覆で $1 / 2$ とした．表-9 に金属被覆の防食寿命が最 長のケースである酸性雨の影響のない一般環境における 防食寿命を, 表-10 に最短ケースである酸性雨条件下の厳 しい環境における防食寿命を示寸.なお, 期間比率とは, 新規 C-5 塗装を基準とした防食寿命の比率である. 表-10 
に示寸ように，金属被覆による防食は，酸性雨環境下に おいて, 重防食塗装よりも防食性能を維持する期間が短 い可能性がある.

\section{c）補修方法}

劣化した金属被覆の補修方法は，環境促進実験の結果 から，悪鉛めっき，合金溶射，およひ擬合金溶射による 金属被覆に関しては，スイープブラストによってさびを 除去し，活膜を残す状態で Rc-I 塗装による塗替え塗装す ることによって，通常の Rc-I 塗装と同等の防食性能が確 保できるとした．アルミ溶射については，活膜の完全な 除去が必要であることから，技術者へのヒアリング調査 をもとに，素地調整費用がスイープブラストの 1.75 倍必 要として算定した．また，比較のため，ヒアリング調査 を参考として，溶射で補修をした場合の算定も行った。

表-11 にそれぞれの防食方法の新規の場合と補修の場合 の費用を示す。

\section{(2) 算定結果}

図-15 に酸性雨の影響なしの一般環境におけるライフ サイクルコストの算定結果を示す，なお，図の横軸は新 規塗装の塗替えまでの期間（通常 30 年〜 60 年）を 1 とし た経過期間である。縦軸は新規塗装費用を 1 としたコス 卜比率である. 図-15に示すように, 長期防食性能を有す る金属被覆を初期に用いた防食システムが，補修方法の 如何に関わらず，塗装による防食システムに比ベコスト 面で有利となる。これは，文献15) と環境促進実験結果 6) をもとに，合金，擬合金，アルミ溶射による金属被覆の 防食寿命を重防食塗装に比べて，表-9 に示寸ように， 2 倍以上と想定したためである.

次に，酸性雨の影響のある厳しい環境における算定結 果を図-16に示す. 図の綐軸と横軸は図-15 と同様である. 図-16に示寸ように, 金属被覆を最初に用いた防食システ ムで，補修法として溶射を選択した場合と，最初から塗 装による防食システムを選択し塗装で補修していく場合 を比較すると，塗装による防食システムで 2 度塗装補修 した段階で，溶射を溶射で補修する場合は，塗装による 防食システムの 2.5 倍のコストがかかり, 非常に不利とな る.しかしながら，最初に金属被覆による防食システム を選択しても，補修法として塗装を選択寸れば，塗装に よる防食システムとのライフサイクルコストの開きは大 きく軽減される。しかし，アルミ溶射の金属皮膜は，塗 装による補修の際に活膜を完全に除去する必要があり, 素地調整費用が高額なため, ライフサイクルコストは 4 種類の金属被覆の中で最大となる.

\section{5. 結論}

本研究において，劣化した金属被覆鋼板の塗装による

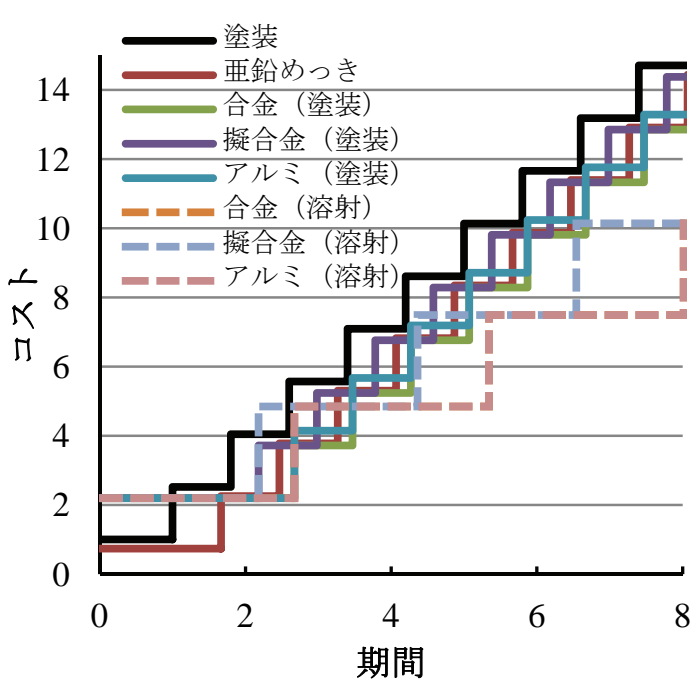

図-15 一般環境（酸性雨影響なし）

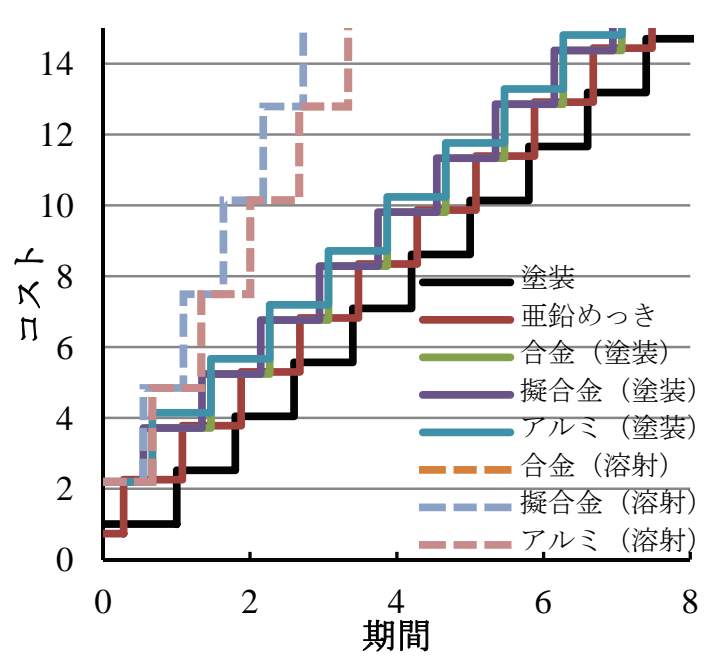

図-16 厳しい環境（酸性雨影響あり）

補修性能を明らかにするために，金属皮膜の残存皮膜を 下地に有寸る塗装補修鋼板の環境促進実験を行った。ま た，その結果を用いて，ライフサイクルコストの算定を 行い，金属被覆による防食システムの維持管理手法につ いて検討し, 以下のような結論が得られた.

1）残存溶融無鉛めっきは, 重防食補修塗装の防食下地 として有益に作用する.

2) 合金溶射と擬合金溶射の残存活膜を残しても，重防 食補修塗装の防食下地として有利には作用しないが, さびを除去し金属活膜が残るスイープブラスト程度 の素地調整で，重防食のみの防食性能とほぼ同等の 防食性能が得られる。しかし, 鋼板素地に達寸るま での深い傷が残存皮膜のある地点に生じた場合，残 存活膜の存在が著しく塗装の防食性能を劣化させる。

3）アルミニウム溶射の残存活膜は, 塗膜による防食に 対して悪影響を及ぼす。その影響度合いは，残存皮 膜厚と相関があり，重防食塗装のみの防食性能と同 等にするためには，残存金属皮膜を完全除去しなけ 
ればならない.

4）仮定にもよるが，酸性雨の影響のない一般環境下に おいては，金属被覆を初期に用いた防食は，その補 修方法の種類に関わらず，塗装による防食に比べて， ライフサイクルコストは小さくなる可能性がある.

5）仮定にもよるが，酸性雨環境下では，劣化金属被覆 鋼板を溶射で補修するよりも，重防食塗装（Rc-I 塗 装系）によって補修する方が，ライフサイクルコス 卜を軽減できる可能性がある.

謝辞 : 本実験における供試体製作に協力いただいた，卜 ピー工業株式会社の長屋五郎氏と，ヒアリング調査に応 じていただいた, 吉川工業株式会社宮村誠一氏, および, $\mathrm{X}$ 線回析に協力していただいた，名古屋大学大学院興戸 正純教授に深くお礼申し上げる.

\section{参考文献}

1) 植野修一:海岸地域において設置後 30 年経過したアルミニ ウム溶射鋼橋の観察報告，防錆管理，Vol.53，pp.134-138, 2009.

2) 奥野眞司，長屋五郎，近藤照夫，松野英則，大柴雅紀 : 金 属溶射材料の種類と防食機構, 防錆管理, Vol.52, pp.145-150, 2008.

3）秋岡幸司，松本雅充，今井和仁，星野信也：東南アジアに おける亜鉛めっき鋼板の 10 年暴露試験結果，防錆管理， Vol.54, pp.204-209, 2010.

4）塗谷紘宣，鈴木紹夫，石川量大，北村義治： $\mathrm{Zn}, \mathrm{Al}$ および Zn-Al 合金溶射皮膜の耐候性，材料と環境，Vol.51， pp.404-409, 2002.

5) 片山英樹，黒田聖治 : 海浜環境に 33 年間暴露された Zn, $\mathrm{Zn}-30 \mathrm{wt} \% \mathrm{Al}$ 及び $\mathrm{Al}$ 溶射皮膜の長期大気腐食挙動，防錆管 理, Vol.54, pp.127-137, 2010.

6) 伊藤義人，清水善行，小山明久 : 酸性雨と塩水噴霧複合少 イクル環境促進実験による金属皮膜防食の耐久性に関する 研究，土木学会論文集 A, Vol.63，No.4，pp.795-810， 2007.

7) 福沢秀刀：剥離腐食と陰極剥離，防錆管理，Vol.53, pp.141-151， 2009.

8) 増子昇：塗膜下腐食の発生と進行，防食技術，Vol.30, pp.699-704, 1981.

9) 伊藤義人，坪内佐織，金仁泰 : 環境促進実験による塗替え 塗装鋼板の腐食劣化特性に関する研究, 土木学会論文集 A, Vol.64, No.3, pp.556-570, 2008.

10）塗谷紘宣，島貢，石川量大，鈴木紹夫，北村義治：溶射皮 膜上に塗装した重防食皮膜の耐力性, 材料と環境, Vol.58, pp.64-70, 2009.

11）藤原博, 田原芳雄 : 鋼橋塗装の長期防食性能の評価に関す る研究，土木学会論文集，No.570/I-40，pp.129-140， 1997.

12）社吋法人 日本道路協会: 鋼道路橋塗装・防食便覧, 2005.

13) 電気事業連合会 : 水門鉄管塗装指針, 1969.

14）関西ペイント株式会社 : 橋梁塗装システムガイドブック, p.113, 2002.

15) 社団法人 日本橋梁建設協会:鋼橋のライフサイクルコスト, 2001.

16）伊藤義人，金仁泰，肥田達久，坪内佐織，忽那幸浩 : 鋼橋 防食に用いられる金属皮膜の防食劣化評価に関する実験的 研究，構造工学論文集，Vol.51A，pp.1059-1067， 2005.

17) 環境省:酸性雨長期モニタリング報告書(平成 15 ～19 年度), pp.101-136, 2009.

(2011. 3.9 受付)

\section{STUDY ON LIFECYCLE PERFORMANCE OF REPAIR PAINTING FOR DETERIORATED METALLIZED STEEL}

\section{Yoshito ITOH, Akihiro HOSOI, Yasuo KITANE, Yuki SUGIURA and Koji KURITA}

Recently, various metallic coating systems have been adopted for steel bridges. In order to examine the performance of repaired painting on steel plates with four types of deteriorated metallic coating systems, acid rain combined cyclic corrosion tests were performed. The four types of metallic coating systems were zinc hot dip galvanized coating, zinc-aluminum alloy coating, zinc-aluminum pseudoalloy coating and aluminum coating. The effect of remaining thickness of metallic coating on the performance of repair paint was discussed. Finally, the lifecycle cost analysis was performed for various repair strategies for the four types of metallic coating systems. 